\title{
Maize-crotalaria intercropping systems
}

\section{Sistemas de consórcio entre milho e crotalária}

\author{
Rafael Torres de Souza; Franciele Caroline de Assis Valadão; \\ Daniel Dias Valadão Júnior ${ }^{2 *}$; Paulo Rogério Guimarães ${ }^{1}$; \\ Vinicius Rossi Ribeiro de Paula ${ }^{1}$
}

\begin{abstract}
The objective of this study was to identify a maize-crotalaria intercropping system feasible for producing straw while maintaining maize yield. A study with a completely randomized block design was performed in 2015 and 2016, with $7 \times 2+1$ split plot and three replications in a clayey Red Oxisol. Seven intercropping systems were allocated to each plot, and two crotalaria species (Crotalaria spectabilis and C. ochroleuca) cultivated with maize in monoculture were allocated to each subplot. Crotalaria yield, total chlorophyll content, nitrogen content, plant height, plant dry matter, thousand grain mass, and corn grain yield were evaluated. $C$. spectabilis was more sensitive to water level variations during the crop cycle than $C$. ochroleuca. Crotalaria sown before maize planting with maize seeds incorporated in the soil presented a relatively higher phytomass but decreased corn grain yield. The management system in which crotalaria was sown in the inter-row with a ridge planter at the time of maize planting and the system in which crotalaria was sown in the maize sowing furrow were feasible for straw production because they did not decrease corn grain yield and did not affect maize harvesting operations.

Key words: Crotalaria spectabilis. Crotalaria ochroleuca. Leguminous plants. Cultivation system.
\end{abstract}

\section{Resumo}

Objetiva-se nesta pesquisa encontrar um sistema de consórcio entre milho e crotalária que seja viável para produção de palhada mantendo a produtividade do milho. Para isso foi instalado nos anos de 2015 e 2016, um experimento em delineamento em blocos casualizados, com arranjo de parcelas subdivididas $7 \times 2+1$ e três repetições em Latossolo Vermelho de textura argilosa, sendo alocado nas parcelas sete formas de consórcio e nas subparcelas as espécies de crotalárias (Crotalaria spectabilis e Crotalaria ocrholeuca) com tratamento adicional sendo o milho solteiro. Foram avaliados atributos produtivos das crotalárias, clorofila e nitrogênio total, altura massa seca da parte aérea, massa de mil grãos e produtividade de grãos. A C. spectabilis se mostrou mais sensível as oscilações hídricas durante o ciclo de desenvolvimento que a $C$. ochroleuca. As crotalárias semeadas antes da cultura do milho com as sementes incorporadas apresentam maior produção de fitomassa, porém, diminuem a produtividade do milho. O manejo em que a crotalária é semeada na entrelinha do milho utilizando sulcador no momento da semeadura do milho bem como aquele em que a crotalária é semeada no sulco de semeadura do milho são viáveis por proporcionarem produção de palhada, não reduzirem a produtividade do milho e não interferirem nas operações de colheita do milho.

Palavras-chave: Crotalaria spectabilis. Crotalaria ocrholeuca. Leguminosas. Sistema de cultivo.

1 Eng ${ }^{\text {os }}$ Agros, Graduados, Instituto Federal de Educação, Ciência e Tecnologia de Mato Grosso, IFMT, Campus Campo Novo do Parecis, MT, Brasil. E-mail: rafaeltorres_94@hotmail.com; paulorogerio_juina@hotmail.com; vinicius_rrp@hotmail.com

2 Profs. Drs., IFMT, Ciência e Tecnologia de Mato Grosso, Campus Campo Novo do Parecis, Campo Novo do Parecis, MT, Brasil. E-mail: franciele.valadao@cnp.ifmt.edu.br; daniel.valadao@cnp.ifmt.edu.br

* Author for correspondence 


\section{Introduction}

In Brazil, maize is the crop that consumes the most nitrogenous fertilizers (CANTARELLA; MARCELINO, 2008), and urea is the most commonly used fertilizer. Urea is preferred because of the lower cost of nitrogen, high solubility, and high nitrogen concentration (45\%). The high concentration of nitrogen reduces the demand amounts, transportation costs, storage, handling, and fertilizer application on the soil and leaves (ERNANI, 2008). However, losses due to volatilization in the form of ammonia $\left(\mathrm{NH}_{3}\right)$ can reach $50 \%$ of the total dose applied and may prevent meeting the needs of the plant (TASCA et al., 2011).

Therefore, alternative methods that improve the efficiency of use of nitrogen in the management system are essential for the sustainability of the productive process. In this respect, crotalaria may play an vital role in reducing the use of synthetic nitrogen sources in maize production. Crotalaria plants can perform the biological fixation of nitrogen (approximately $305 \mathrm{~kg} \mathrm{ha}^{-1}$ of nitrogen) (PERIN et al., 2004) and may be intercropped with other crops to increase yield and reduce the costs of nitrogen fertilization.

Therefore, intercropping leguminous plants with grasses increases the cultivation area, and the grasses can be benefited by the nitrogen fixed by leguminous plants either by the direct release of nitrogen compounds or nitrogen production by the decomposition of nodules and roots during the development of the primary crop (CASTRO et al., 2004).

The use of crotalaria in a single-crop system is unattractive to the farmer because it does not bring direct financial return except in cases of seed production. However, intercropping with maize may increase straw production, which is a fundamental prerequisite for using no-tillage systems without competing for cultivation areas with the primary crop. One of the benefits of these systems is the increase in the organic matter contents of the soil.
In this respect, Heinrichs et al. (2005), Gitti et al. (2012), and Chieza et al. (2017) demonstrated that intercropping systems are feasible by increasing dry matter production per area and grain yield.

In turn, the best maize-crotalaria intercropping system is a matter of debate by farmers, especially for use in large areas. The best system should provide better development of both crops without reducing the yield of the primary crop (maize in this case) and provide soil cover sufficient to suppress the emergence of weeds and allow nutrient cycling. The objective of this study is to identify a maizecrotalaria intercropping system that is feasible for straw production and capable of maintaining grain yield.

\section{Materials and Methods}

The experiment was performed in February 2015 and February 2016 in the experimental area of the Federal Institute of Education, Science, and Technology of Mato Grosso, Campo Novo do Parecis campus, in a typical Dystrophic Red Latosol according to the guidelines of the Brazilian Soil Classification System (EMBRAPA, 2013), with the following chemical and textural characteristics at the depth $0-0.20 \mathrm{~m}$ in the year 2015 according to Embrapa (2009): $\mathrm{pH}$ in $\mathrm{CaCl}_{2}, 6.4$; organic matter, $31.0 \mathrm{~g} \mathrm{dm}^{-3}$; phosphorus (P), $9.80 \mathrm{mg} \mathrm{dm}^{-3}$; potassium $\left(\mathrm{K}^{+}\right), 53.00 \mathrm{mg} \mathrm{dm}{ }^{-3}$; calcium $\left(\mathrm{Ca}^{2+}\right), 3.10$ cmolc $\mathrm{dm}^{-3}$; magnesium $\left(\mathrm{Mg}^{2+}\right), 1.16$ cmolc $\mathrm{dm}^{-3}$; aluminum $\left(\mathrm{Al}^{3+}\right), 0.0 \mathrm{cmolc} \mathrm{dm}^{-3} ; \mathrm{H}+\mathrm{Al}, 3.33$ cmolc $\mathrm{dm}^{-3}$; TCC, $7.72 \mathrm{cmolc} \mathrm{dm}^{-3}$; clay content, $506 \mathrm{~g} \mathrm{~kg}^{-}$ ${ }^{1}$, silt content, $134 \mathrm{~g} \mathrm{~kg}^{-1}$, and sand content, $360 \mathrm{~g}$ $\mathrm{kg}^{-1}$.

The experimental area was located at the latitude $13^{\circ} 40^{\prime} 31^{\prime} \mathrm{S}$, longitude $57^{\circ} 53^{\prime} 31^{\prime \prime} \mathrm{W}$, and altitude of $572 \mathrm{~m}$. The climate of the region is hot and humid (Aw) according to Köppen's classification (ALVARES et al., 2013). The temperature and precipitation data in the study period are shown in Figure 1. 
Figure 1. Rainfall and temperature data in the study period in the years 2015 (A) and 2016 (B). Campo Novo do Parecis, Mato Grosso, Brazil.
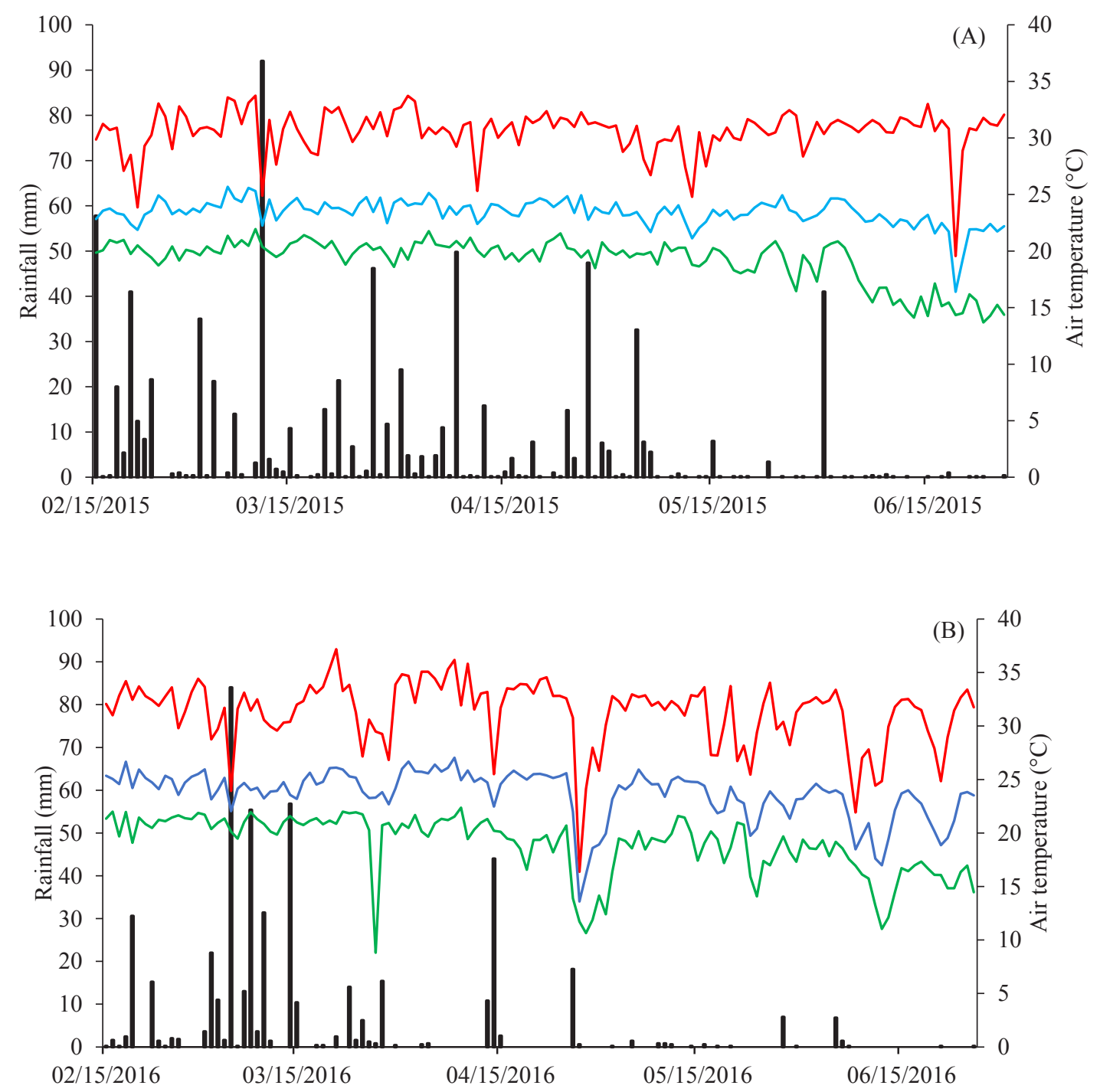

Rainfall $\longrightarrow$ Maximum temperature Average temperature Minimum temperature

The study used a completely randomized block design with $7 \times 2+1$ split plot and three replicates. The following maize-crotalaria intercropping systems were used in each plot: M1, broadcast sowing of crotalaria 15 days before maize planting using a disk harrow; M2, broadcast sowing of crotalaria 15 days before maize planting without maize seed incorporation; M3, broadcast sowing of crotalaria immediately after maize planting without maize seed incorporation; M4, crotalaria sowing between maize rows using a ridge planter immediately after maize planting; M5, crotalaria sowing in the maize sowing furrow; M6, crotalaria sowing between maize rows using a ridge planter 15 days after maize planting; M7, broadcast sowing of crotalaria without seed incorporation 15 days after maize planting. Two crotalaria species ( $C$. spectabilis and $C$. ochroleuca) were used in the subplots. The additional treatment was maize crop in monoculture. 
Maize was sown on February 28, 2015, and on February 27, 2016, in an area previously cultivated with soybean and desiccated with $0.96 \mathrm{~kg} \mathrm{ha}^{-1}$ of glyphosate. After desiccation, the experimental plots were demarcated, with each unit constituting an area of $12.6 \mathrm{~m}^{2}(3.15 \times 4.0 \mathrm{~m})$, with seven sowing rows. The hybrid CD $333 \mathrm{HX}$ with early cycle and caterpillar resistance was used. The interrow spacing was $0.45 \mathrm{~m}$, and plant density was 2.7 seeds per meter at a seeding depth of $0.03 \mathrm{~m}$. The three central rows were considered the useful area, discarding $0.5 \mathrm{~m}$ on each side.

No liming was required according to soil analysis, and the amount of fertilizer was determined according to the needs of the maize crop. The formulation $\mathrm{N}-\mathrm{P}_{2} \mathrm{O}_{5}-\mathrm{K}_{2} \mathrm{O}$ ) 10-14-20 at a dose of 300 $\mathrm{kg} \mathrm{ha}^{-1}$ was added to the maize sowing furrow. For topdressing fertilization, only one dose of fertilizer was used when maize was in $\mathrm{V} 6$, with $70 \mathrm{~kg} \mathrm{ha}^{-1}$ of nitrogen and $30 \mathrm{~kg} \mathrm{ha}^{-1}$ of $\mathrm{K}_{2} \mathrm{O}$ in the form of urea and potassium chloride, respectively (SOUSA; LOBATO, 2004).

Pest density was monitored every 7 days in three random sites of one linear meter in each treatment by counting the number of insects. The most abundant insect species were the belly-green bug (Dichelops melacanthus), which were managed with acephate at the dose of $0.750 \mathrm{~kg} \mathrm{ha}^{-1}$ in V3, and the fall armyworm (Spodoptera frugiperda), which were managed with two applications of chlorfenapyr at the dose of $0.120 \mathrm{~kg} \mathrm{ha}^{-1}$. The fungicide epoxiconazole was applied in V8 and V13 for managing white spot, helmintosporiosis, and cercosporiosis. Weeds were controlled manually in the plots.

Crotalaria plants were evaluated during maize harvesting by measuring plant height, distance from the soil surface to the last pod in the main stem of the plant, and shoot dry matter by randomly collecting all the plants from two $0.25 \mathrm{~m}^{2}$-squares.
After collection, the plants were conditioned in an oven at $65{ }^{\circ} \mathrm{C}$ and weighed weekly until reaching a constant mass.

At the R1 stage of maize development, total chlorophyll content was determined using a chlorophyll meter. The determination was carried out on the flag leaf of four different plants within the useful area of the plot. The leaves were collected, dried in a forced circulation oven at $60{ }^{\circ} \mathrm{C}$, and ground, and the total nitrogen content was measured according to Embrapa (2009). Fifteen plants of each plot were randomly harvested in a useful area when the crop reached the harvest point. The measured parameters were height, shoot dry matter, thousand grain mass, and grain yield (in $\mathrm{kg} \mathrm{ha}^{-1}$ ), correcting the values to $13 \%$ of humidity.

The results were subjected to analysis of variance and, when F was significant $(\mathrm{p}<0.05)$, Dunnett's test was applied to compare the factorial structure with maize crop in monoculture. The Scott-Knott test was used for factorial analysis, respecting the respective interactions. Statistical analysis was performed using the statistical software ASSISTAT (SILVA; AZEVEDO, 2009).

\section{Results and Discussion}

In the two study years, there was an interaction effect between shoot height and dry matter of crotalaria (Table 1). In the year 2015, the highest height of crotalaria plants was obtained in the system in which seeds were sown at 15 days after maize planting without seed incorporation (M7). This result was probably due to the availability of water in the germination and emergence stages (Figure 1A), which ensured plant development. However, the growth of crotalaria plants was reduced because the maize crop was in a more advanced stage of development. 
Table 1. Mean values of height and dry matter of crotalaria as a function of intercropping with maize. Campo Novo do Parecis, Mato Grosso, Brazil, 2015 and 2016.

\begin{tabular}{|c|c|c|c|c|c|c|c|c|}
\hline \multirow{2}{*}{ Crotalaria } & \multicolumn{7}{|c|}{ Intercropping system } & \multirow{2}{*}{$\mathrm{CV} \%$} \\
\hline & M1 & M2 & M3 & M4 & M5 & M6 & M7 & \\
\hline \multicolumn{9}{|c|}{2015} \\
\hline \multicolumn{9}{|c|}{ Height (m) } \\
\hline C. spectabilis & $0.93 \mathrm{cA}$ & $1.16 \mathrm{Ba}$ & $0 \mathrm{eA}$ & $0.77 \mathrm{dA}$ & $1.06 \mathrm{cA}$ & $0.96 \mathrm{cB}$ & $1.36 \mathrm{aB}$ & \multirow{2}{*}{6.45} \\
\hline C. ochroleuca & $0.95 \mathrm{cA}$ & $0.60 \mathrm{~dB}$ & $0 \mathrm{eA}$ & $1.03 \mathrm{cA}$ & $1.20 \mathrm{bA}$ & $1.23 \mathrm{bA}$ & $1.55 \mathrm{aA}$ & \\
\hline \multicolumn{9}{|c|}{ Dry matter $\left(\mathrm{kg} \mathrm{ha}^{-1}\right)$} \\
\hline C. spectabilis & $3,260 \mathrm{aA}$ & $1,330 \mathrm{cA}$ & $0 \mathrm{~dB}$ & $330 \mathrm{dA}$ & $2,130 \mathrm{bA}$ & $1,460 \mathrm{cA}$ & $1,003 \mathrm{cA}$ & \multirow[t]{2}{*}{59.05} \\
\hline C. ochroleuca & 3,460 aA & $530 \mathrm{cA}$ & $0 \mathrm{cA}$ & $1,930 \mathrm{bA}$ & $1,200 \mathrm{bA}$ & $1,200 \mathrm{bA}$ & $1,000 \mathrm{cA}$ & \\
\hline \multicolumn{9}{|c|}{2016} \\
\hline \multicolumn{9}{|c|}{ Height (m) } \\
\hline C. spectabilis & $0.60 \mathrm{cA}$ & $0 \mathrm{dA}$ & $0 \mathrm{dA}$ & $0.96 \mathrm{bA}$ & $1.35 \mathrm{aA}$ & $0.76 \mathrm{bA}$ & $0 \mathrm{dA}$ & \multirow{2}{*}{20.10} \\
\hline C. ochroleuca & $0.65 \mathrm{cA}$ & $0 \mathrm{dA}$ & $0 \mathrm{dA}$ & $0.59 \mathrm{cB}$ & $1.20 \mathrm{aB}$ & $0.55 \mathrm{cB}$ & $0 \mathrm{bA}$ & \\
\hline \multicolumn{9}{|c|}{ Dry matter $\left(\mathrm{kg} \mathrm{ha}^{-1}\right)$} \\
\hline C. spectabilis & $2,380 \mathrm{aA}$ & $0 \mathrm{dA}$ & $0 \mathrm{dA}$ & $1,250 \mathrm{cB}$ & $1,620 \mathrm{bB}$ & $1,000 \mathrm{cA}$ & $0 \mathrm{dA}$ & \multirow{2}{*}{39.10} \\
\hline C. ochroleuca & $2,390 \mathrm{aA}$ & $0 \mathrm{cA}$ & $0 \mathrm{cA}$ & $1,670 \mathrm{bA}$ & $1,970 \mathrm{aA}$ & $1,270 \mathrm{bA}$ & $0 \mathrm{Ca}$ & \\
\hline
\end{tabular}

The means followed by the same letter were not significantly different from each other using the Scott-Knott test at a level of significance of 5\%. Uppercase letters compared rows, and lowercase letters compared columns. M1, broadcast sowing of crotalaria 15 days before maize planting using a disk harrow; M2, broadcast sowing of crotalaria 15 days before maize planting without maize seed incorporation; M3, broadcast sowing of crotalaria immediately after maize planting without maize seed incorporation in the soil; M4, crotalaria sowing between maize rows using a ridge planter immediately after maize planting; M5, crotalaria sowing in the maize sowing furrow; M6, crotalaria sowing between maize rows using a ridge planter 15 days after maize planting; M7, broadcast sowing of crotalaria without seed incorporation in the soil 15 days after maize planting.

In 2016, crotalaria seeds did not germinate in the treatments with broadcast sowing, and the plants grew only in the treatments in which the seeds were incorporated into the soil (M1, M4, M5, and M6). These results differ from those of Timossi et al. (2011), who evaluated crotalaria yield as a function of the sowing method and found no significant difference between conventional and broadcast sowing. However, the water level variations were higher in 2016 than in 2015, with the rainfall concentrated in the first weeks of the study period followed by water deficits (Figure 1B).

In 2015 and 2016, shoot dry matter was higher in system M1 (Table 1). Therefore, as the objective of using cover crops is dry matter production, this type of management is best because incorporated seeds have greater contact with the soil, providing the best development of the plant as a result of the higher use of nutrients and water (GITTI et al., 2012). In contrast, in practice, seed incorporation in the soil using a disk plow would be indicated only in the first year because plowing might adversely affect the no-tillage system. Therefore, the management systems involving crotalaria sowing in the interrow at the time of maize planting (M4), crotalaria sowing in the maize sowing furrow (M5), and crotalaria sowing in the inter-row by disc plowing at 15 days after maize planting (M6) also ensured the contact of the seeds with the soil, allowing the competition between the cover plants and maize in the two study periods. These results are in line with those of Heinrichs et al. (2005), Pereira et al. (2011), and Chieza et al. (2017), who demonstrated the competitive capacity of crotalaria intercropped with maize without decreasing the dry matter yield of the cover crop. 
Another critical factor is that the cover crop planted in the maize sowing furrow (M5) makes better use of the fertilizer under the seeds, resulting in higher competition with the maize crop and producing satisfactory results (FARINELLI; LEMOS, 2010). In addition, sowing operations, including the use of small seeds adapted for corn seeders, are comparatively easier.

The dry matter yield of crotalaria in all systems was lower than the values reported in the literature (GITTI et al., 2012; COSTA et al., 2014; DEBIASI et al., 2016; CHIEZA et al., 2017) but similar to the results of Heinrichs et al. (2005). The benefits of soil cover and dry matter yield depend on the sowing season. For this reason, dry matter tends to be higher when sowing is performed in the summer when the risk of water deficiency is lower (GITTI et al., 2012; CHIEZA et al., 2017). Another relevant factor is the period after maize harvest in which crotalaria has higher dry matter accumulation.

There was an interaction effect for the chlorophyll content only in 2015 (Table 2). For the two species of crotalaria, the chlorophyll content was comparatively higher when the seeds were sown and incorporated before maize planting (M1), and this system also provided higher chlorophyll concentrations than maize crops cultivated as a single-crop system. The other treatments were not significantly different from the control. In 2016, only the systems in which crotalaria and maize were sown together either in the same sowing furrow (M5) or in the inter-row (M4) had a total chlorophyll content similar to that of the control, whereas the concentrations in the other management systems were lower than those of the control.

Table 2. Mean values of total chlorophyll and nitrogen content of maize as a function of intercropping with crotalaria. Campo Novo do Parecis, Mato Grosso, Brazil, 2015 and 2016.

\begin{tabular}{|c|c|c|c|c|c|c|c|c|}
\hline \multirow{2}{*}{ Crotalaria } & \multicolumn{7}{|c|}{ Intercropping system } & \multirow{2}{*}{$\mathrm{CV} \%$} \\
\hline & M1 & M2 & M3 & M4 & M5 & M6 & M7 & \\
\hline \multicolumn{9}{|c|}{2015} \\
\hline \multicolumn{9}{|c|}{ Total chlorophyll content } \\
\hline C. spectabilis & $51.18 \mathrm{bB} *$ & $58.83 \mathrm{aA}$ & $52.43 \mathrm{bA}^{*}$ & $46.93 \mathrm{cA}^{*}$ & $49.35 \mathrm{cA}^{*}$ & $53.60 \mathrm{bA}^{*}$ & $52.91 \mathrm{bA} *$ & \\
\hline C. ochroleuca & $57.83 \mathrm{aA}$ & $51.76 \mathrm{bB} *$ & $52.20 \mathrm{bA} *$ & $48.65 \mathrm{bA}^{*}$ & $49.03 \mathrm{bA}^{*}$ & $51.66 \mathrm{bA} *$ & $50.25 \mathrm{bA}^{*}$ & 6.54 \\
\hline \multirow{2}{*}{\multicolumn{9}{|c|}{$\frac{48.01^{*}}{\text { Nitrogen content }\left(\mathrm{g} \mathrm{kg}^{-1}\right)}$}} \\
\hline & & & & & & & & \\
\hline C. spectabilis & $22.96 \mathrm{aA}^{*}$ & $20.17 \mathrm{bB} *$ & $19.77 \mathrm{bB}^{* *}$ & $24.32 \mathrm{aA}^{*}$ & $21.07 \mathrm{bA}^{*}$ & $22.76 \mathrm{aA}^{*}$ & $19.17 \mathrm{bB}^{*}$ & \\
\hline C. ochroleuca & $21.72 \mathrm{bA}^{*}$ & $23.77 \mathrm{aA} *$ & $24.90 \mathrm{aA}$ & $23.71 \mathrm{aA}^{*}$ & $20.77 \mathrm{bA}^{*}$ & $22.01 \mathrm{bA}^{*}$ & $24.07 \mathrm{aA} *$ & 7.43 \\
\hline Control sample & & & & $22.70 *$ & & & & \\
\hline \multicolumn{9}{|c|}{2016} \\
\hline \multicolumn{9}{|c|}{ Total chlorophyll content } \\
\hline $\begin{array}{l}\text { C. spectabilis } \\
\text { C. ochroleuca }\end{array}$ & $46.24 \mathrm{~d}$ & $46.01 \mathrm{~d}$ & $44.18 \mathrm{~d}$ & $51.45 \mathrm{~b}^{*}$ & $54.84 \mathrm{a}^{*}$ & $47.42 \mathrm{c}$ & $48.42 \mathrm{c}$ & 5.52 \\
\hline Control sample & & & & $52.80 *$ & & & & \\
\hline \multicolumn{9}{|c|}{ Nitrogen content $\left(\mathrm{g} \mathrm{kg}^{-1}\right)$} \\
\hline C. spectabilis & $26.46 \mathrm{bA}^{*}$ & $23.60 \mathrm{cA}^{*}$ & $22.69 \mathrm{cA}^{*}$ & $24.68 \mathrm{cA}^{*}$ & $29.75 \mathrm{aA}$ & $22.35 \mathrm{cA}^{*}$ & $23.24 \mathrm{cB}^{*}$ & \\
\hline C. ochroleuca & $24.73 \mathrm{aA}^{*}$ & $24.06 \mathrm{aA}^{*}$ & $24.89 \mathrm{aA}^{*}$ & $24.42 \mathrm{aA}^{*}$ & $23.28 \mathrm{aB}^{*}$ & $24.35 \mathrm{aA}^{*}$ & $26.69 \mathrm{aA} *$ & 7.43 \\
\hline Control sample & & & & $22.91 *$ & & & & \\
\hline
\end{tabular}

The means followed by the same letter were not significantly different from each other using the Scott-Knott test at a level of 
significance of 5\%. Uppercase letters compare rows, and lowercase letters compared columns. The means marked with an asterisk (*) do not differ from the control using Dunnett's test at a level of significance of 5\%. M1, broadcast sowing of crotalaria 15 days before maize planting using a disk harrow; M2, broadcast sowing of crotalaria 15 days before maize planting without maize seed incorporation in the soil; M3, broadcast sowing of crotalaria immediately after maize planting without maize seed incorporation in the soil; M4, crotalaria sowing between maize rows using a ridge planter immediately after maize planting; M5, crotalaria sowing in the maize sowing furrow; M6, crotalaria sowing between maize rows using a ridge planter 15 days after maize planting; M7, broadcast sowing of crotalaria without seed incorporation in the soil 15 days after maize planting.

There was an interaction effect for total nitrogen in the two study periods. In 2015, the systems in which crotalaria seeds were incorporated to the soil before maize planting (M1), in the inter-row at the time of maize planting (M4), and in the inter-row at 15 days after maize planting (M6) resulted in higher nitrogen contents in maize crops (Table 2). However, none of the evaluated systems differed from maize in monoculture, indicating that the competition with maize in the intercropping systems did not affect the nitrogen levels in maize crop. Silva and Menezes (2007) observed that fertilization with green manure allowed nitrogen mobilization throughout the cultivation period, demonstrating that crop management was performed for at least two years.

In 2016, there was no difference between the management systems using $C$. ochroleuca. However, for C. spectabilis, nitrogen content was comparatively higher in the system in which the leguminous plant was cultivated together with maize in the sowing furrow (M5), with nitrogen content of $29.75 \mathrm{~g} \mathrm{~kg}^{-1}$, and this was the only system in which the nitrogen content was higher than that of maize used as a single-crop system, and the other systems were not significantly different from that of the control.

The treatments that produced the highest nitrogen levels in maize had a higher total chlorophyll content. This result indicates that the increase in leaf nitrogen is reflected directly in the chlorophyll content because nitrogen is part of the chlorophyll molecule. The relationship between these two variables indicates that the measuring the chlorophyll content is better than measuring the nitrogen content for determining the nutritional status of the plant because measurements using the chlorophyll meter are easier and do not destroy leaf tissues (VARGAS et al., 2012).

It is worth noting that most of the values of the chlorophyll and nitrogen content in maize leaves were outside the range of 55 to 58 and 28 to $35 \mathrm{~g} \mathrm{~kg}^{-1}$ of nitrogen, respectively, which is considered ideal for maize development (MALAVOLTA, 2006). Nonetheless, maize growth was not impaired, and the leaves did not present symptoms of nitrogen deficiency. Furthermore, these results cannot be attributed to competition in the management system because the nitrogen concentrations of maize in monoculture were also lower than those recommended for the culture.

Farinelli and Lemos (2010) used different nitrogen concentrations in maize cover crop and found that at $120 \mathrm{~kg} \mathrm{ha}^{-1}$ of nitrogen, the leaf nitrogen content was similar to that found in this study. However, the other treatments with $C$. spectabilis (M1) and C. ochroleuca (M1 and M7) produced a similar leaf nitrogen content when $80 \mathrm{~kg} \mathrm{ha}^{-1}$ of nitrogen was used. Nitrogen levels in the remaining treatments were similar to those obtained at a dose of $40 \mathrm{~kg} \mathrm{ha}^{-1}$ of nitrogen. Tasca et al. (2011) reported that losses of nitrogen fertilizer by volatilization and leaching might prevent meeting the needs of the plant. In this case, intercropping with crotalaria may prevent these losses because the nitrogen provided to the soil by these plants is in organic form, and the losses would be lower.

Crotalaria can fix approximately $305 \mathrm{~kg} \mathrm{ha}^{-1}$ of nitrogen, and the decomposition of its straw would result in a nutritional gain by the subsequent crop (PERIN et al., 2004). Silva et al. (2009) evaluated nitrogen utilization by maize as a function of green 
manuring with crotalaria and millet and concluded that the nitrogen utilization of nitrogen by maize was higher in the presence of millet. Crotalaria can provide nitrogen to maize when cultivated and managed at the right time, and maize grain production with intercropping is similar to that of maize monoculture with cover cropping (CHIEZA et al., 2017). The genetic potential of straw production and the pivotal development of the root system of crotalaria species are beneficial characteristics in areas under no-tillage to increase the organic matter content, improve soil structure, and increase nitrogen concentration in the soil (GITTI et al., 2012).
There was an interaction effect for maize plant height in 2015 and 2016 (Table 3). The management system in which crotalaria was sown broadcast at 15 days before maize planting (M1) provided the lowest maize height using both $C$. spectabilis and C. ochroleuca compared to maize in monoculture. Among the systems in which crotalaria grew in the first year, C. ochroleuca provided lower maize height than $C$. spectabilis in the system that used broadcast sowing before maize planting without seed incorporation (M2) and in the system in which crotalaria was sown in the inter-row (M4). There was no significant difference between the two species of crotalaria in the other systems.

Table 3. Mean values of height and shoot dry matter of maize as a function of intercropping with crotalaria. Campo Novo do Parecis, Mato Grosso, Brazil, 2015 and 2016.

\begin{tabular}{|c|c|c|c|c|c|c|c|c|}
\hline \multirow{2}{*}{ Crotalaria } & \multicolumn{7}{|c|}{ Intercropping system } & \multirow{2}{*}{$\mathrm{CV} \%$} \\
\hline & M1 & M2 & M3 & M4 & M5 & M6 & M7 & \\
\hline \multicolumn{9}{|c|}{2015} \\
\hline \multicolumn{9}{|c|}{ Stem height (m) } \\
\hline C. spectabilis & $2.15 \mathrm{bA}$ & $2.53 \mathrm{aA}^{*}$ & $2.50 \mathrm{aA} *$ & $2.59 \mathrm{aA}$ & $2.47 \mathrm{aA}^{*}$ & $2.52 \mathrm{aA}^{*}$ & $2.53 \mathrm{aA}^{*}$ & \\
\hline C. ochroleuca & $2.17 \mathrm{cA}$ & $2.42 \mathrm{bB}^{*}$ & $2.55 \mathrm{aA} *$ & $2.50 \mathrm{aB}^{*}$ & $2.51 \mathrm{aA}^{*}$ & $2.51 \mathrm{aA}^{*}$ & $2.55 \mathrm{aA} *$ & 2.31 \\
\hline \multirow{2}{*}{\multicolumn{9}{|c|}{$\frac{2.48^{*}}{\text { Stem dry matter }\left(\mathrm{kg} \mathrm{ha}^{-1}\right)}$}} \\
\hline & & & & & & & & \\
\hline C. spectabilis & $9,193 \mathrm{bA}$ & $11,077 \mathrm{aA}$ & $11,617 \mathrm{aA}$ & $11,125 \mathrm{aA}$ & $10.825 \mathrm{aA}$ & $11,495 \mathrm{aA}$ & $11,334 \mathrm{aA}$ & \\
\hline C. ochroleuca & $7,879 \mathrm{bB}$ & $10,216 \mathrm{aB}$ & $11,065 \mathrm{aB}$ & $8,808 \mathrm{bB}$ & $8,817 \mathrm{bB}$ & $9,123 \mathrm{bB}$ & $10,354 \mathrm{aB}$ & 19.51 \\
\hline Control sample & & & & Control sample & & & & \\
\hline \multicolumn{9}{|c|}{2016} \\
\hline \multicolumn{9}{|c|}{ Stem height $(\mathrm{m})$} \\
\hline C. spectabilis & $1.57 \mathrm{cA}$ & $1.78 \mathrm{aA}$ & $1.69 \mathrm{aB}^{*}$ & $1.63 \mathrm{bA}^{*}$ & $1.74 \mathrm{aA}^{*}$ & $1.74 \mathrm{aB}^{*}$ & $1.66 \mathrm{bB} *$ & \\
\hline C. ochroleuca & $1.55 \mathrm{dA}$ & $1.70 \mathrm{bC}$ & $1.80 \mathrm{aA}$ & $1.66 \mathrm{cA}^{*}$ & $1.68 \mathrm{cB}^{*}$ & $1.81 \mathrm{aA}$ & $1.73 \mathrm{bA}^{*}$ & 3.14 \\
\hline Control sample & & & & $1.65^{*}$ & & & & \\
\hline \multicolumn{9}{|c|}{ Stem dry matter $\left(\mathrm{kg} \mathrm{ha}^{-1}\right)$} \\
\hline $\begin{array}{l}\text { C. spectabilis } \\
\text { C. ochroleuca }\end{array}$ & $4,968 \mathrm{~b}$ & $6,084 a^{*}$ & $5,809 \mathrm{a}^{*}$ & $6,196 a^{*}$ & $6,056 a^{*}$ & $6,065 a^{*}$ & $6,050 a^{*}$ & 13.57 \\
\hline Control sample & & & & $6,121^{*}$ & & & & \\
\hline
\end{tabular}

The means followed by the same letter were not significantly different from each other using the Scott-Knott test at a level of significance of 5\%. Uppercase letters compare rows, and lowercase letters compared columns. The means marked with an asterisk (*) do not differ from the control using Dunnett's test at a level of significance of 5\%. M1, broadcast sowing of crotalaria 15 days before maize planting using a disk harrow; M2, broadcast sowing of crotalaria 15 days before maize planting without maize seed incorporation in the soil; M3, broadcast sowing of crotalaria immediately after maize planting without maize seed incorporation in the soil; M4, crotalaria sowing between maize rows using a ridge planter immediately after maize planting; M5, crotalaria sowing in the maize sowing furrow; M6, crotalaria sowing between maize rows using a ridge planter 15 days after maize planting; M7, broadcast sowing of crotalaria without seed incorporation in the soil 15 days after maize planting. 
In 2016, in plots in which crotalaria was sown in the inter-row 15 days after maize planting (M6), C. ochroleuca provided higher maize height than $C$. spectabilis, and there were no significant differences between the two species of crotalaria in the other systems. The difference between the crotalaria species in M2, M3, and M7 cannot be attributed to the cover crop because the leguminous plants did not grow in these systems (Table 2). In most intercropping systems in the two study periods, there was no significant difference in maize plant height when compared to maize in monoculture, and this result is due to the competitive advantage of maize relative to crotalaria species (GITTI et al., 2012).

In 2015, maize intercropped with $C$. spectabilis had a higher shoot dry matter than maize intercropped with $C$. ochroleuca, and all intercropping systems differed from maize in monoculture, whereas only M1 using both crotalaria species and M4, M5, and M6 using C. ochroleuca provided lower shoot dry matter than maize as a single crop. Dry matter accumulation was higher in the other systems compared to M1 (Table 3). In 2016, there was an interaction effect for the management systems, and only M1 provided a lower shoot dry matter than maize in monoculture. Shoot dry matter production was similar in the other systems, and there was no significant difference in this parameter between the two species of crotalaria (Table 3).

Maize plant height affected dry matter production, and smaller plants had a lower dry matter, and this result was more evident in areas where crotalaria seeds were sown broadcast and incorporated to the soil using a disk harrow (M1). This system provided higher dry matter accumulation by the cover crop and, consequently, might have stronger competition with maize, reducing mass gain. Another potential contributing factor is soil tillage, which leaves the soil exposed and accelerates the decomposition of organic matter, reducing water retention in the soil (COSTA et al., 2014). Moreover, situations of water deficit or water level variations, such as those observed in this study, may decrease the development and dry matter accumulation of maize.

C. spectabilis has been shown to compete less with maize and have a relatively lower impact on maize development and dry matter accumulation. Gitti et al. (2012) studied a maize-crotalaria intercropping system and found that $C$. spectabilis had no adverse effect on maize development and increased dry matter yield.

There was no interaction effect for thousand grain mass in 2015. In 2016, there was a significant difference between the intercropping systems but no significant difference between the two species of crotalaria (Table 4). All systems in which crotalaria grew (M1, M4, M5, and M6) provided higher thousand grain mass in maize crop compared to the systems in which crotalaria did not grow (M2, M3, and M7). Management system M5 provided higher grain mass than maize in a single crop, and the other systems were not significantly different from M5.

There was an interaction effect for corn grain yield in the two study years (Table 4). In 2015, there was a tendency for $C$. ochroleuca to provide higher grain yield relative to $C$. spectabilis, i.e., the higher dry matter accumulation in the latter was not reflected in higher yield. For C. spectabilis, the grain yields were relatively lower in M1 and M5 but similar in the other systems. Gitti et al. (2012) found that the use of $C$. spectabilis and an intercropping system seeded at maize stages V7 and R4 produced higher grain yields than maize in a single-crop system.

In 2016, there was a substantial decrease in crop yield in all systems compared to 2015 because of the water deficit in the crops during the development cycle (Figure 1B), resulting in lower values of several parameters, including plant height, mass gain, shoot dry matter, and thousand grain mass. For Sousa et al. (2015), decreased maize yield due to water deficiency may be attributed to the synchronism between tasseling, which usually occurs earlier, and silking, which occurs later, 
resulting in pollen grain abortion or poor viability of pollen grains at the time of emission of stigma styles, resulting in the formation of spikes with few or no grains.

Table 4. Mean values for a thousand grain mass and corn grain yield as a function of intercropping with crotalaria. Campo Novo do Parecis, Mato Grosso, Brazil, 2015 and 2016.

\begin{tabular}{|c|c|c|c|c|c|c|c|c|}
\hline \multirow{3}{*}{ Crotalaria } & \multicolumn{7}{|c|}{ Intercropping system } & \multirow{3}{*}{$\mathrm{CV} \%$} \\
\hline & M1 & M2 & M3 & M4 & M5 & M6 & M7 & \\
\hline & \multicolumn{7}{|c|}{2015} & \\
\hline \multicolumn{9}{|c|}{ Thousand grain mass $(\mathrm{g})$} \\
\hline C. spectabilis & 384.11 & 375.20 & 397.20 & 371.53 & 372.29 & 371.25 & 377.54 & \\
\hline C. ochroleuca & 373.93 & 393.20 & 380.82 & 376.57 & 398.63 & 377.23 & 390.18 & 6.45 \\
\hline Control sample & & & & & & & & \\
\hline \multicolumn{9}{|c|}{$\frac{229.37^{*}}{\text { Yield }\left(\mathrm{kg} \mathrm{ha}^{-1}\right)}$} \\
\hline C. spectabilis & $6,187 \mathrm{bB}$ & $8,649 \mathrm{aA}^{*}$ & $8,344 \mathrm{aA}^{*}$ & $8,259 \mathrm{aA}^{*}$ & $5,960 \mathrm{bB}$ & $8,091 \mathrm{aA}$ & $7,820 \mathrm{aA}$ & \\
\hline C. ochroleuca & $9,416 \mathrm{aA} *$ & $8,024 \mathrm{bA}$ & $8,112 \mathrm{bA}$ & $7,172 \mathrm{bA}$ & $7,918 \mathrm{bA}$ & $7,795 \mathrm{bA}$ & $7,856 \mathrm{bA}$ & 13.03 \\
\hline Control sample & & & & Control sample & & & & \\
\hline & & & & 2016 & & & & \\
\hline \multicolumn{9}{|c|}{ Thousand grain mass (g) } \\
\hline $\begin{array}{l}\text { C. spectabilis } \\
\text { C. ochroleuca }\end{array}$ & $251.77 \mathrm{a}$ & $240.17 \mathrm{~b}$ & $242.35 \mathrm{~b}$ & $250.07 \mathrm{a}$ & $255.91 \mathrm{a}$ & $233.62 b^{*}$ & $249.19 \mathrm{a}$ & 6.54 \\
\hline Control sample & & & & $229.37 *$ & & & & \\
\hline \multicolumn{9}{|c|}{ Yield $\left(\mathrm{kg} \mathrm{ha}^{-1}\right)$} \\
\hline C. spectabilis & 3,436 aA & $3,140 \mathrm{bA}$ & $3,202 \mathrm{bb}$ & $4,345 \mathrm{aA}^{*}$ & $4,424 \mathrm{aA}^{*}$ & $4,837 \mathrm{aA}^{*}$ & $3,920 \mathrm{aA}$ & \\
\hline C. ochroleuca & $3,838 \mathrm{aA}^{*}$ & $3,677 \mathrm{aA}$ & $3,963 \mathrm{aA}$ & $3,491 \mathrm{Ab}$ & $2,954 \mathrm{bB}$ & $3,999 \mathrm{aB} *$ & $3,823 \mathrm{aA}^{*}$ & 13.53 \\
\hline Control sample & & & & $4,236^{*}$ & & & & \\
\hline
\end{tabular}

The means followed by the same letter were not significantly different from each other using the Scott-Knott test at a level of significance of 5\%. Uppercase letters compare rows, and lowercase letters compared columns. The means marked with an asterisk (*) do not differ from the control using Dunnett's test at a level of significance of 5\%. M1, broadcast sowing of crotalaria 15 days before maize planting using a disk harrow; M2, broadcast sowing of crotalaria 15 days before maize planting without maize seed incorporation in the soil; M3, broadcast sowing of crotalaria immediately after maize planting without maize seed incorporation in the soil; M4, crotalaria sowing between maize rows using a ridge planter immediately after maize planting; M5, crotalaria sowing in the maize sowing furrow; M6, crotalaria sowing between maize rows using a ridge planter 15 days after maize planting; M7, broadcast sowing of crotalaria without seed incorporation in the soil 15 days after maize planting.

Water deficits decreased crop yield in the intercropping systems compared to 2015. Intercropping with $C$. spectabilis in the inter-row at the time of maize planting (M4) increased grain yield, and plant sowing 15 days before maize planting (M1) resulted in the lowest grain yield. In the management system with C. ochroleuca, only M1 system decreased grain yield, and the other systems were not significantly different between each other and were similar to maize as a single-crop system.
In 2016, intercropping with C. spectabilis resulted in higher grain yields than $C$. ochroleuca, and this may be because $C$. ochroleuca accumulated more dry matter than $C$. spectabilis, demonstrating that $C$. ochroleuca is tolerant to water level variations during the study period, leading to higher competitiveness with maize and lower grain yield. The competition for water, nutrients, and light between crops, especially in the grain filling stage, is more evident in water-deficient conditions 
(SOUSA et al., 2015; CHIEZA et al., 2017), as the condition observed in the second year. Chieza et al. (2009) evaluated maize intercropped with green manure and found that water restriction conditions adversely affected cereal grain production. Debiasi et al. (2016) compared soybean yield using different plant covers and found that crop yield using $C$. spectabilis straw was higher than that using $C$. ochroleuca straw. However, this system was viable because it did not reduce maize yield compared to the control. Another advantage in the use of crotalaria is that annual cultivation can reduce the population density of Pratylenchus brachyurus by up to $75 \%$ (COSTA et al., 2014; DEBIASI et al., 2016). In addition, management systems using crotalaria between maize rows can decrease the weed population (TIMOSSI et al., 2011).

The constant and slow growth rate of $C$. spectabilis and $C$. ochroleuca and the lower height reached by these species (1.2-1.5 m) are advantages in the intercropping system with maize because they decreased competition and did not affect the mechanized harvest of maize (GITTI et al., 2012). In addition, these species can be used in agricultural systems without competing for areas planted with commercial crops.

Heinrichs et al. (2005), Chieza et al. (2009), and Chieza et al. (2017) demonstrated that there was no adverse effect of intercropping with crotalaria on maize yield and there was a beneficial effect in subsequent years in the same cultivated area. Moreover, in this crop system, the leguminous plant has a physiological advantage because it is more efficient in carbon fixation and dry matter accumulation at higher temperatures.

The use of green manure with crotalaria causes desirable changes in the chemical, physical, and biological attributes of the soil, allowing the maintenance of fertility. The biological fixation of nitrogen and the availability of other nutrients are significantly increased over the years (SCHEUER; TOMASI, 2011). The results of this study demonstrate the sustainability of these production systems, reducing environmental damage from industrialized inputs and increasing economic viability.

\section{Conclusions}

Crotalaria spectabilis was more responsive to water level variations during the crop development cycle than C. ochroleuca.

Crotalaria sown before maize planting with seed incorporation in the soil presented a relatively higher phytomass but decreased corn grain yield.

The intercropping system in which crotalaria was sown between maize rows using a ridge planter at the time of maize planting and the system in which crotalaria was sown in the maize sowing furrow are recommended because they allow straw production, do not reduce corn grain yield, and do not affect maize harvesting operations.

\section{Acknowledgments}

To CNPq for providing a scholarship and to the Federal Institute of Education and Technology of Mato Grosso for funding this project.

\section{References}

ALVARES, C. A.; STAPE, J. L.; SENTELHAS, P. C.; GONÇAVES, J. L. M.; SPAVOREK, G. Koppen's climate classification map for Brazil. Meteorologische Zeitschrift, Stuttgart, v. 22, n. 6, p. 711-728, 2013. DOI: 10.1127/0941-2948/2013/0507

CANTARELLA, H.; MARCELINO, R. Fontes alternativas de nitrogênio para a cultura do milho. Informações Agronômicas, Piracicaba, n. 122, p. 12-14, 2008.

CASTRO, C. M.; ALVES, B. J. R.; ALMEIDA, D. L. Adubação verde como fonte de nitrogênio para a cultura da berinjela em sistema orgânico. Pesquisa Agropecuária Brasileira, Brasília, v. 39, n. 8, p. 779-785, 2004.

CHIEZA, E. D.; GUERRA, J. G. M.; ARAÚJOS, E. S.; ESPÍNDOLA, J. A.; FERNANDES, R. C. 
Produção e aspectos econômicos de milho consorciado com Crotalária juncea L. em diferentes intervalos de semeadura sob manejo orgânico. Revista Ceres, Viçosa, v. 64, n. 2, p. 189-196, 2017. DOI: 10.1590/0034737X201764020012

CHIEZA, E. D.; LOVATO, T.; RODRIGUES, J.; PIZZANI, R.; PIAIA, Â.; TONIN, J.; SCHAEFER, P. E.; JONER, G.; MACHADO, D. S. Produtividade do milho e produção de fitomassa em cultivo solteiro ou consorciado com leguminosas sob diferentes formas de adubação. Revista Brasileira de Agroecologia, Cruz Alta, v. 4, n. 2, p. 1932-1934, 2009.

COSTA, N. R.; ANDREOTTI, M.; BUZETTI, S.; LOPES, K. S. M.; SANTOS, F. G.; PARIZ, C. M. Acúmulo de macronutrientes e decomposição da palhada de braquiárias em razão da adubação nitrogenada durante e após o consórcio com a cultura do milho. Revista Brasileira de Ciência do Solo, Viçosa, v. 38, n. 5, p. 12231233, 2014. DOI: 10.1590/S0100-06832014000400019

DEBIASI, H.; FRANCHINI, J. C.; DIAS, W. P.; RAMMOS JUNIOR, E. U.; BALBINOT JÚNIOR, A. A. Práticas culturais na entressafra da soja para o controle de Pratylenchus brachyurus. Pesquisa Agropecuária Brasileira, Brasília, v. 51, n. 10, p. 1720-1728, 2016. DOI: $10.1590 / \mathrm{s} 0100-204 \times 2016001000003$

EMPRESA BRASILEIRA DE PESQUISA AGROPECUÁRIA - EMBRAPA. Manual de análises químicas de solos, plantas e fertilizantes. 2. ed. Brasília: EMBRAPA Informação Tecnológica, 2009.

EMPRESA BRASILEIRA DE PESQUISA AGROPECUÁRIA - EMBRAPA. Sistema brasileiro de classificação de solos. 3. ed. Brasília: Embrapa, 2013.

ERNANI, P. R. Química do solo e disponibilidade de nutrientes. Lages: O Autor, 2008. 230 p.

FARINELLI, R.; LEMOS, L. B. Produtividade e eficiência agronômica do milho em função da adubação nitrogenada e manejos do solo. Revista Brasileira de Milho e Sorgo, Sete Lagoas, v. 9, n. 2, p. 135-146, 2010. DOI: $10.18512 / 1980-6477 /$ rbms.v9n2p135-146

GITTI, D. C.; ARF, O.; VILELA, R. G.; PORTUGAL, J. R.; KANEKO, F. H.; RODRIGUES, R. A. F. Épocas de semeaduras de crotalária em consórcio com milho. Revista Brasileira de Milho e Sorgo, Sete Lagoas, v. 11, n. 2 , p. 156-168, 2012. DOI: 10.18512/1980-6477/rbms. v11n2p156-168

HEINRICHS, R.; VITTI, G. C.; MOREIRA, A.; FIGUEIREDO, P. A. M.; FANCELLI, A. L.; CORAZZA, E. J. Características químicas de solo e rendimento de fitomassa de adubos verdes e de grãos de milho, decorrente do cultivo consorciado. Revista Brasileira de
Ciência do Solo, Viçosa, v. 29, n. 1, p. 71-79, 2005.

MALAVOLTA, E. Manual de nutrição mineral de plantas. Piracicaba: Ceres, 2006. 631 p.

PEREIRA, L. C.; FONTANETTI, A.; BATISTA, J. N.; GALVÃO, J. C.; GOULART, P. L. Comportamento de cultivares de milho consorciados com Crotalaria juncea: estudo preliminar. Revista Brasileira de Agroecologia, Cruz Alta, v. 6, n. 3, p. 191-200, 2011.

PERIN, A.; SANTOS, R. H. S.; URQUIAGA, S.; GUERRA, J. G. M.; CECON, P. R. Produção de fitomassa, acúmulo de nutrientes e fixação biológica de nitrogênio por adubos verdes em cultivo isolado e consorciado. Pesquisa Agropecuária Brasileira, Brasília, v. 39, n. 1, p. 35-40, 2004.

SCHEUER, J. M.; TOMASI, D. B. A crotalária na adubação intercalar e reforma do cultivo de cana-deaçúcar. Vivências: Revista Eletrônica de Extensão da URI, Erechim, v. 7, n. 12, p. 81-90, 2011.

SILVA, E. C.; MURAOKA, T.; VILLANUEVA, F. C. A.; ESPINAL, F. S. C. Aproveitamento de nitrogênio pelo milho, em razão da adubação verde, nitrogenada e fosfatada. Pesquisa Agropecuária Brasileira, Brasília, v. 44, n. 2, p. 118-127, 2009.

SILVA, F. A. S.; AZEVEDO, C. A. V. Principal components analysis in the software Assistat -statistical attendance. In: WORLD CONGRESS ON COMPUTERS IN AGRICUlTURE, 7., 2009, Reno. Proceedings... St. Joseph: American Society of Agricultural and Biological Engineers, 2009.

SILVA, F. A. S.; AZEVEDO, C. A. V. The Assistat Software Version 7.7 and its use in the analysis of experimental data. African Journal of Agricultural Research. Nairobi, v. 11, n. 39, p. 3733-3740, 2016. DOI: 10.5897/AJAR2016.11522

SILVA, T. O.; MENEZES, R. S. C. Adubação orgânica da batata com esterco e, ou, Crotalaria juncea. II Disponibilidade de N, P e K no solo ao longo do ciclo de cultivo. Revista Brasileira de Ciência do Solo, Viçosa, v. 31, n. 1, p. 51-61, 2007.

SOUSA, D. M. G.; LOBATO, E. Cerrado: correção do solo e adubação. 2. ed. Brasília: EMBRAPA Informação Tecnológica, 2004. 416 p.

SOUSA, R. S.; BASTOS, E. A.; CARDOSO, M. J.; RIBEIRO, V. Q.; BRITO, R. R. Desempenho produtivo de genótipos de milho sob déficit hídrico. Revista Brasileira de Milho e Sorgo, Sete Lagoas, v. 14, n. 1, p. 49-60, 2015. DOI: 10.18512/1980-6477/rbms.v14n1p49-60

TASCA, F. A.; ERNANI, P. R.; ROGERI, D. A.; GATIBONI, L. C.; CASSOL, P. C. Volatilização de 
amônia do solo após aplicação de ureia convencional ou com inibidor de urease. Revista Brasileira de Ciência do Solo, Viçosa, v. 35, n. 3, p. 493-502, 2011.

TIMOSSI, P. C.; WISINTAINER, C.; SANTOS, B. J.; PEREIRA, V. A.; PORTO, V. S. Supressão de plantas daninhas e produção de sementes de crotalária em função de métodos de semeadura. Pesquisa Agropecuária Tropical, Goiânia, v. 41, n. 4, p. 525-530, 2011.
VARGAS, V. P.; LUIS SANGOI, P.; ERNANI, P. R.; SIEGA, E.; CARNIEL, G.; FERREIRA, M. A. Os atributos nas folhas são mais eficientes que o $\mathrm{N}$ mineral no solo para avaliar a disponibilidade desse nutriente para o milho. Bragantia, Campinas, v. 71, n. 2, p. 245255, 2012. 
